\title{
EKSPERIMENTASI MODEL PEMBELAJARAN TAI AFL TERHADAP HASIL BELAJAR MATEMATIKA SISWA SMP PADA MATERI BILANGAN
}

\author{
Adi Nurcahyo ${ }^{1}$, Nugroho Arif Sudibyo ${ }^{2}$, \\ 1,2 Universitas Muhammadiyah Surakarta, Universitas Duta Bangsa Surakarta \\ an123@ums.ac.id ${ }^{1}$,nugroho_arif@udb.ac.id ${ }^{2}$
}

\begin{abstract}
:
This research aims to determine the effect of the use of AfL TAI learning models on learning outcomes in grade VII students with number material. The research method used quasi-experimental research with cluster random sampling data collection techniques. The population in this study was students of VII grade at SMPN 2 Colomadu in academic year 2018/2019. While the sample in the study is VII grade students consisting of three classes and totaling 90 peoples. Data collection using documentation and test methods in the form of multiple choice questions as many as 20 questions. The analysis prerequisite test uses the Liliefors method as a normality test and Bartlet test as a homogeneity test. Data analysis used one-way analysis of variance with the same cell and then continued post-anava test with the Scheffe test. Based on the research results obtained that TAI AfL learning model is more effective than the TAI learning model and direct model, besides that the TAI learning model is more effective than the direct learning model
\end{abstract}

Keywords: TAI, AfL, Assessment, Direct Learning.

\begin{abstract}
Abstrak :
Penelitian ini bertujuan untuk mengetahui pengaruh penggunaan model pembelajaran TAI AfL terhadap hasil belajar pada siswa kelas VII dengan materi bilangan. Metode penelitian yang digunakan yaitu eksperimental semu dengan teknik pengambilan data cluster random sampling. Populasi dalam penelitian yaitu siwa kelas VII di SMPN 2 Colomadu tahun ajaran 2018/2019. Sedangkan sampel pada penelitian yaitu siswa kelas VII yang terdiri dari tiga kelas dan berjumlah 90 orang. Pengumpulan data menggunakan metode dokumentasi dan metode tes yang berupa soal pilihan ganda sebanyak 20 soal. Uji prasyarat analisis menggunakan metode Liliefors sebagai uji normalitas dan uji Bartlet sebagai uji homogenitas. Analisis data menggunakan analisis variansi satu jalur dengan sel sama kemudian dilanjutkan uji lanjut pasca anava dengan uji Scheffe. Berdasarkan hasil penelitian didapatkan hasil model pembelajaran TAI AfL lebih efektif daripada model pembelajaran TAI dan model langsung, selain itu juga model pembelajaran TAI lebih efektif daripada model pembelajaran secara langsung.
\end{abstract}

Kata Kunci : TAI, AfL, Asesmen, Pembelajaran Langsung.

Received: June 25, 2020 / Accepted: July 27, 2020 / Published Online: August 26, 2020 


\section{PENDAHULUAN}

Pendidikan merupakan usaha manusia untuk mengubah dan membina kepribadian berlandaskan dengan nilai-nilai baik di dalam masyarakat maupun kebudayaan melalui proses Pendidikan (Supriyanti, 2020). Kegiatan interaksi antara guru dengan siswa dapat diperhatikan dari proses pembelajaran yang berlangsung. Pembelajaran diharapkan dapat menciptakan ketertarikan pada siswa dalam hal merangsang pemikiran, mengembangkan keterampilan dalam berpikir atau merancang sesuatu untuk saling berinteraksi dengan dunia (Mawaddah \& Maryanti, 2016, Biggs dalam Goldman \& Torrisi-Steele, 2002). Dalam proses pembelajaran, guru tidak hanya menyampaikan ilmu pengetahuan kepada siswa saja tetapi dapat menjadikan siswa aktif dalam pembelajaran dan terpacu untuk mengembangkan kemampuannya. Oleh karenanya, guru harus menguasai materi dengan baik dan dapat mengelola kelas agar siswa dapat memahami materi yang diberikan.

Upaya-upaya telah dilakukan untuk meningkatkan kualitas pendidikan yang ada, diantaranya dengan cara memperbaiki pelaksanaan proses pembelajaran di sekolah. Akan tetapi usaha-usaha yang telah dilakukan masih belum menunjukkan hasil sesuai dengan yang diharapkan. Khususnya pada pelajaran matematika, prestasi belajar yang didapat siswa masih cenderung rendah. Padahal alokasi jam pelajaran matematika lebih banyak dibandingkan mata pelajaran lain yang ada di sekolah.

Data dari Puspendik Kemdikbud (Puspendik, 2017), rerata nilai ujian nasional SMP Negeri pada tahun pelajaran 2017/2018 untuk mata pelajaran matematika di Kabupaten Karanganyar yaitu 55,65. Dilihat dari rerata tersebut, tentunya ada permasalahan dalam prestasi belajar matematika. Sementara itu, jika dilihat dari penguasaan materi dalam ujian nasional, persentase siswa yang menjawab benar pada materi bilangan sebesar 50,58\%, Aljabar 60,17\%, Geometri dan Pengukuran 51,97\%, dan Statistika dan Peluang 67\%. Berdasarkan data tersebut, siswa SMP Negeri di Kabupaten Karanganyar mengalami kesulitan dalam menyelesaikan permasalahan yang berkaitan dengan materi bilangan.

Fakta yang didapat dari hasil observasi di SMPN 2 Colomadu yaitu pembelajaran yang dilakukan oleh guru matematika diantaranya guru menjelaskan materi yang diajarkan, kemudian memberikan contoh soal dari materi yang diberikan, siswa mengerjakan latihan soal yang diberikan secara individu yang selanjutnya beberapa siswa diminta maju untuk mengerjakan di depan kelas. Pada tahap akhir, guru memberikan PR kepada siswa. Pembelajaran berdasarkan observasi yang telah dilakukan cenderung menyebabkan siswa kurang berpartisipasi aktif dalam pembelajaran. Dari hasil pengamatan yang dilakukan, kurang lebih hanya $30 \%$ siswa yang aktif berpartisipasi dalam pembelajaran. Hal ini dapat dilihat dari siswa yang mengacungkan tangan saat siswa diminta maju untuk mengerjakan soal di depan kelas. Sehingga pembelajaran terkesan monoton dan kurang menarik, hal ini berakibat pada kurang maksimalnya hasil belajar matematika.

Data hasil ulangan harian matematika kelas VII yang diambil pada saat observasi belum menunjukkan hasil yang maksimal. Pada materi bilangan bulat, sebanyak 30\% siswa yang memenuhi 
KKM. Materi operasi hitung sebanyak 38,3\% siswa yang nilainya memenuhi KKM, dan pada materi kelipatan dan faktor sebanyak 37\% siswa yang memenuhi KKM. Dari hasil tersebut menunjukkan bahwa hasil belajar siswa masih kurang memuaskan.

Dari hasil observasi yang dilakukan, diperlukan usaha yang dapat meningkatkan partisipasi siswa dan berdampak pada hasil belajar siswa. Model pembelajaran yang sesuai dapat membantu keefektifan, kelancaran dan efisiensi untuk mencapai tujuan pembelajaran. Dengan adanya model pembelajaran di kelas yang sesuai, siswa dapat memahami materi yang disampaikan dan menyelesaikan berbagai masalah yang diberikan oleh guru. Agus Suprijono (2011) menyatakan bahwa dalam teori belajar konstruktivisme dalam pembelajaran, semua pengetahuan merupakan hasil konstruksi dari kegiatan atau tindakan yang dilakukan oleh seseorang. Menurut Rakhmawati (2015) model pembelajaran kooperatif dapat meningkatkan partisipasi siswa. Sejalan dengan itu, Attle \& Baker (2007) dengan adanya pembelajaran kooperatif, terjadi adanya peningkatan hubungan interpersonal positif dan kesehatan mental bagi siswa dibandingkan dengan penggunaan pembelajaran individual. Dengan adanya keterlibatan dengan orang lain, siswa dapat melakukan evaluasi dan memperbaiki pemahaman saat adanya partisipasi bersama (Agus Suprijono, 2011). Oleh karenanya, dalam pelaksanaan pembelajaran menggunakan model pembelajaran kooperatif dengan pendekatan konstruktivisme untuk membangun kerangka pemikiran belajar bagi siswa sebagai proses belajar yang kooperatif antara guru dan siswa.

Salah satu model pembelajaran kooperatif yaitu Team Assisted Individualization (TAI). Model pembelajaran kooperatif TAI merupakan model pembelajaran yang dapat meningkatkan partisipasi aktif siswa (Asriningsih et al., 2014; Cahyani et al., 2018; Hariyati et al., 2013; Tinungki, G., 2015). Menurut Slavin (2010) adanya penerapan model TAI dalam pembelajaran matematika dipelopori sebagai kegiatan atau usaha merancang pembelajaran yang dilakukan secara individu dapat menyelesaikan masalah-masalah efektifitas dalam pembelajaran individu. Ciri model pembelajaran TAI yaitu siswa secara individu belajar materi yang telah diberikan kemudian hasilnya didiskusikan dalam kelompok untuk dibahas antar anggota kelompok dan hasil diskusi merupakan tanggung jawab bersama (Tristanti, 2017).

Penelitian yang dilakukan Tarim \& Akdeniz (2008) menyimpulkan bahwa model pembelajaran TAI lebih efektif daripada model STAD dan model pembelajaran konvensional dalam meningkatkan prestasi belajar matematika siswa. Noor \& Munandar (2019) juga mengungkapkan bahwa model pembelajaran kooperatif tipe TAI dan TPS meningkatkan hasil belajar matematika. Tristanti (2017) menyimpulkan penggunaan model pembelajaran kooperatif TAI dan problem based learning (PBL) memberikan pengaruh terhadap pemahaman konsep matematika. Dewi \& Yulia (2018) juga menyimpulkan model pembelajaran TAI efektif terhadap prestasi belajar siswa. Senada dengan itu, Achdiyat \& Andriyani (2016) dalam penelitiannya juga menyimpulkan hasil belajar siswa yang diajar dengan TAI lebih tinggi daripada yang diajar dengan model konvensional. Langkah-langkah model 
pembelajaran TAI menurut Slavin (2010) meliputi: 1) Teams (siswa belajar dalam kelompok kecil yang heterogen dan beranggotakan 4-5 orang ), 2) Placement Test (kemampuan awal yang diambil dari pretest atau hasil tes sebelumnya), 3) Teaching Group (guru menjelaskan materi dengan memperkenalkan konsep pada siswa), 4) Student Creative (siswa diminta membaca, memahami, dan mengerjakan tugas yang diberikan secara individu), 5) Team Study (siswa diberikan lembar kerja siswa (LKS) untuk dibahas dalam kelompok masing-masing, 6) Whole Class Unit (siswa mempresentasikan hasil pekerjaan kelompoknya dan ditanggapi kelompok lain, kemudian siswa menarik kesimpulan dari diskusi yang dilakukan), 7) Fact Test (guru memberikan tes untuk mengetahui kemampuan siswa dan diberikan di akhir pembelajaran), 8) Team Scores dan Team Recognition (menghitung skor kelompok di akhir pembelajaran).

Selain faktor model pembelajaran, faktor yang berpengaruh terhadap hasil belajar yaitu model penilaian yang digunakan guru. Guru menilai hasil pekerajaan siswa tanpa memberikan umpan balik kepada siswa (Kholid, 2015). Penggunaan penilaian atau asesmen dalam pembelajaran akan melengkapi penggunaan model pembelajaran. Salah satu bentuk asesmen diantaranya Assessment for Learning (AfL). Menurut Irving (2006) pengukuran prestasi siswa dapat dimaksimalkan dengan melakukan asesmen dalam pembelajaran. Asesmen ini berupa asesmen formatif. Asesmen formatif berfungsi sebagai sarana bagi guru untuk memberikan balikan (feed-back) kepada siswa secepat mungkin (Budiyono, 2011). Sejalan dengan hal tersebut, Gunawan (2017) menyimpulkan model pembelajaran berbasis AfL dapat dijadikan referensi dalam pembelajaran di kelas. Berdasarkan dari permasalahan yang telah dikemukakan, model pembelajaran TAI dengan menggunakan AfL dapat menjadi alternatif model pembelajaran kooperatif yang dapat dilakukan di sekolah. Dengan penggunaan model pembelajaran TAI berbasis AfL diharapkan dapat meningkatkan pemahaman siswa dalam mata pelajaran matematika.

\section{METODE PENELITIAN}

Penelitian ini dilaksanakan di SMP N 2 Colomadu yang beralamat di Nanasan, Malangjiwan, Kecamatan Colomadu, Kabupaten Karanganyar, Jawa Tengah. Pada penelitian ini, jenis penelitian yang digunakan yaitu penelitian eksperimental semu karena peneliti tidak dapat melakukan kontrol terhadap semua variabel yang relevan. Sugiyono (2011) menyatakan penelitian eksperimental semu terdapat kelompok kontrol, tetapi kelompok kontrol tersebut tidak bisa secara keseluruhan melakukan kontrol terhadap variabel dari luar yang mempengaruhi eksperimen. Populasi pada penelitian ini yaitu seluruh siswa SMP kelas VII di SMPN 2 Colomadu tahun ajaran 2018/2019. Siswa kelas VII di SMPN 2 Colomadu terdiri dari tujuh kelas dengan jumlah siswa sebanyak 221 orang. Sampel untuk penelitian ini diambil tiga kelas yaitu kelas VII A, VII B, dan kelas VII C dengan masing-masing kelas terdiri dari 30 siswa. 
Teknik pengambilan sampel yang digunakan yaitu cluster random sampling. Pengambilan sampel secara tidak langsung ke dalam pengamatan dengan mengambil sebuah sampel dari kelompokkelompok bagian pengamatan yang ada untuk memilih sampel penelitian (Fadila, 2016). Penentuan kelompok eksperimen dan kontrol dilakukan dengan sistem pengundian. Ketiga kelas yang muncul dijadikan sampel. Berdasarkan hasil pengundian didapat kelas VII A sebagai kelas kontrol dengan model pembelajaran langsung, kelas VII B sebagai kelas eksperimen dengan model pembelajaran TAI, dan kelas VII C sebagai kelas eksperimen dengan model pembelajaran TAI AfL.

Teknik pengumpulan data yang digunakan yaitu metode dokumentasi dan metode tes. Metode dokumentasi diambil dari nilai ulangan harian siswa pada materi bilangan bulat. Nilai ini digunakan untuk mengetahui kemampuan awal siswa. Dengan menggunakan uji analisis variansi, didapat ketiga kelas mempunyai kemampuan awal yang sama. Sedangkan untuk metode tes digunakan untuk mendapatkan data hasil belajar matematika. Metode tes yang digunakan berupa soal pilihan ganda sebanyak 20 soal dengan empat pilihan jawaban. Setelah proses validasi, metode tes yang disusun telah dinyatakan valid oleh validator yaitu Bp. Widodo, S. Pd selaku guru di SMPN 2 Colomadu dan Ibu Sri Slamet, S. Pd selaku guru di SMPN 3 Colomadu. Skor reliabilitas instrumen tes hasil belajar yaitu 0,834 yang menandakan bahwa instrumen tersebut reliabel.

Teknik analisis data dalam penelitian ini yaitu analisis variansi satu jalan dengan masing-masing sel sama kemudian dilanjutkan menggunakan uji komparasi ganda dengan metode Scheffe. Sebelum diberikan perlakuan, uji normalitas diterapkan pada data yang dikumpulkan dengan menggunakan uji Lilliefors dan menggunakan uji homogenitas variansi dengan menggunakan metode Barttlet.

\section{HASIL DAN PEMBAHASAN}

Dalam penelitian ini, instrument soal yang digunakan diujicobakan terlebih dahulu untuk mengetahui validitas dan reliabilitas soal. Ujicoba dilakukan di kelas VII G SMPN 2 Colomadu. Setelah instrumen valid dan reliabel kemudian digunakan untuk penelitian. Hasil uji kemampuan awal diambil dari uji keseimbangan menggunakan nilai ulangan harian materi bilangan bulat. Hasil uji keseimbangan awal yang dilakukan terhadap ketiga sampel didapat nilai $F_{\text {hitung }}=1,449$, sedangkan nilai $F_{\text {tabel }}\left(F_{0,05 ; 2 ; 87}\right)$ $=3,10$. Hal ini menandakan bahwa tidak terdapat perbedaan kemampuan awal yang berarti sampel berasal dari populasi dengan kemampuan awal yang seimbang.

Eksperimen semu yang dilakukan dengan memberikan model pembelajaran yang berbeda pada tiga kelas. Kelas VII A diberikan model pembelajaran langsung, kelas VII B diberikan model pembelajaran dengan menggunkan TAI, dan kelas VII C diberikan model pembelajaran TAI AfL. Setelah diberi perlakuan, masing-masing kelas diberikan tes hasil belajar yang digunakan untuk mendapatkan data tes hasil belajar matematika. Hasil analisis deskriptif yang didapat dari tes hasil belajar yang diberikan disajikan pada tabel 1 . 
Tabel 1. Analisis Deskriptif Statistik

\begin{tabular}{lccc}
\hline Model & Mean & Std.Deviation & $\mathrm{N}$ \\
\hline Pembelajaran Langsung & 60,83 & 3,152 & 30 \\
\hline TAI & 64,14 & 3,203 & 30 \\
\hline TAI AfL & 68,7 & 3,446 & 30 \\
\hline
\end{tabular}

Setelah diketahui hasil analisis deskriptif yang berupa nilai rata-rata dan standar deviasi dari masing-masing kelas, kemudian dicari normalitas dan homogenitas sebagai syarat uji prasyarat analisis sebelum dilakukan analisis variansi. Hasil uji normalitas dan homogenitas ditampilkan pada tabel 2 dan tabel 3 .

Tabel 2. Uji Normalitas

\begin{tabular}{lccc}
\hline \multicolumn{4}{c}{ Shapiro-Wilk } \\
\hline Variabel & Statistic & df & Sig. \\
\hline Pembelajaran Langsung & 0,958 & 30 & 0,274 \\
\hline TAI & 0,941 & 30 & 0,095 \\
\hline TAI AfL & 0,973 & 30 & 0,625 \\
\hline
\end{tabular}

Tabel 3. Uji Homogenitas

\begin{tabular}{llll}
\hline Levene Statistic & $\mathrm{dk} 1$ & $\mathrm{dk} 2$ & Sig. \\
\hline 0,010 & 2 & 87 & 0,933 \\
\hline
\end{tabular}

Dari Tabel 2 dapat ditarik kesimpulan bahwa ketiga model sudah terdistribusi normal. Hal ini menandakan bahwa tiap-tiap model pembelajaran memiliki nilai signifikansi lebih dari 5\%, sehingga $\mathrm{H}_{0}$ diterima yang berarti sampel yag didapat berasal dari populasi dengan distribusi normal. Pada tabel 3, nilai signifikansi sebesar $0,933>0,05$ yang berarti variansinya homogen. Sehingga dapat ditarik kesimpulan bahwa data sampel yang didapat memiliki variansi yang homogen. Oleh karena itu, dapat dilakukan uji analisis variansi satu jalan secara seksama menggunakan taraf signifikansi dengan alpha $5 \%$ yang tertera pada tabel 4 .

Tabel 4. Hasil Uji ANAVA Satu Jalan dengan Sel Sama

\begin{tabular}{cccccc}
\hline Sumber & JK & Dk & RK & F & Sig. \\
\hline Perlakuan & 936,289 & 2 & 468,144 & 43,797 & 0,000 \\
Galat & 929,933 & 87 & 10,689 & & \\
\hline Total & 1866,222 & 89 & & & \\
\hline
\end{tabular}


Berdasarkan output pada tabel 4 diperoleh nilai $\mathrm{Sig}=0,000<0,05$ sehingga dapat disimpulkan $\mathrm{H}_{0}$ ditolak. Selain dari nilai Sig, bisa juga dilihat dari nilai F pada tabel kolom F. Dari tabel tersebut didapat $F_{\text {hitung }}=43,797>\mathrm{F}_{\text {tabel }}=3,101$ sehingga $\mathrm{H}_{0}$ ditolak. Jadi terdapat perbedaan hasil belajar pada materi bilangan dari ketiga model pembelajaran yang dilakukan. Hasil penelitian yang dilakukan dengan menggunakan model pembelajaran TAI AfL terlihat siswa lebih aktif dalam pembelajaran. Siswa lebih komunikatif dan berpartisipasi aktif dalam kegiatan kelompok. Sehingga dengan adanya penerapan model pembelajaran suasana belajar siswa menjadi lebih menyenangkan. Penggunaan model pembelajaran kooperatif TAI AfL dan TAI memberikan pengaruh yang baik terhadap prestasi belajar siswa (Halih, 2016; Jaya et al., 2016; Pajriana \& Pujilestari, 2018). Penerapan model pembelajaran TAI AfL maupun TAI mendukung adanya pengelompokan siswa, pengelompokan kemampuan siswa di dalam kelas, dan pengajaran yang terprogram (Pajriana \& Pujilestari, 2018). Siswa dapat menemukan letak kesulitan-kesulitan yang dialami dalam pembelajaran dan mencari solusi untuk mengatasi permasalahan yang ada. Penerapan model pembelajaran TAI bertujuan untuk mengurangi pengajaran individual yang kurang efektif, meningkatkan pengetahuan, kemampuan dan motovasi dengan adanya belajar denagn tim (Huda, 2014). Selanjutnya, untuk melihat perbedaan hasil belajar antar model pembelajaran dapat diketahui dengan melakukan uji Scheffe sebagai uji setelah melakukan analisis variansi. Data uji Scheffe disajikan pada Tabel 5.

Tabel 5. Uji Lanjut Pasca ANAVA (Uji Scheffe)

\begin{tabular}{llcc}
\hline $\begin{array}{c}\text { Model } \\
\text { Pembelajaran (i) }\end{array}$ & Pembelajaran (j) & $\begin{array}{c}\text { Mean } \\
\text { Difference (i-j) }\end{array}$ & Signifikansi \\
\hline Langsung & TAI & $-3,300$ & 0,001 \\
& TAI AfL & $-7,867$ & 0,000 \\
\hline TAI & Langsung & 3,300 & 0,001 \\
& TAI AfL & $-4,567$ & 0,000 \\
\hline TAI AfL & Langsung & 7,867 & 0,000 \\
& TAI & 4,567 & 0,000 \\
\hline
\end{tabular}

Dari Uji Lanjut Scheffe dapat disimpulkan bahwa antara model TAI AfL dan TAI memiliki nilai probabilitas Sig. 0,00<0,05 yang menyatakan ada perbedaan antara TAI AfL dan TAI. Dengan melihat mean difference antara TAI AfL dan TAI, dapat dicermati bahwa dengan menggunakan model TAI AfL lebih efektif daripada menggunakan model TAI. Penerapan asesmen dalam pembelajaran khususnya AfL memberikan pengaruh positif terhadap siswa. Ada beberapa keuntungan yang didapat siswa dalam penerapan AfL pada pembelajaran. Siswa dapat menilai kinerja pribadi dan teman serta saling memberikan umpan balik terhadap hasil pekerjaan yang dilakukan (Isabwe et al., 2014). Senada dengan itu, Sutriningsih (2015) dalam penelitiannya juga menyatakan model pembelajaran TAI AfL lebih baik dari model pembelajaran TAI. Hal ini dikarenakan adanya modifikasi dengan AfL dapat membantu guru 
untuk menentukan posisi pemahaman siswa terhadap suatu materi dalam pebelajaran, kemudian menentukan cara terbaik mengenai apa yang sebaiknya dilakukan guru. Sehingga hasil yang muncul sesuai dengan beberapa penelitian yang telah didapat sebelumnya yaitu dengan adanya penambahan AfL dalam model pembelajaran TAI dapat memberikan pengaruh yang baik terhadap hasil belajar matematika.

Pada model pembelajaran TAI dengan model pembelajaran langsung didapat nilai signifikansi 0,001 yang berarti yaitu kurang dari 0,05 . Berarti ada perbedaan antara model pembelajaran TAI dengan dengan model pembelajaran langsung. Dilihat dari mean differencenya model TAI lebih baik dari pembelajaran langsung. Menurut Cahyani et al (2018) model pembelajaran TAI memberikan pengaruh yang positif berkaitan dengan hasil belajar matematika. Sehingga tentunya model TAI memberikan pengaruh yang lebih baik daripada pembelajaran langsung. Adanya kekurangan pada model pembelajaran langsung diantaranya disebabkan guru masih dominan dalam pembelajaran, dimana guru bersifat aktif dan siswa bersifat pasif (Afifah et al., 2018).

\section{KESIMPULAN}

Berdasarkan penelitian yang telah dilakukan, didapat kesimpulan bahwa nilai signifikansi antara model pembelajaran TAI AfL dengan TAI, TAI AfL dengan pembelajaran langsung, dan TAI dengan pembelajaran langsung nilai signifikansinya $<0,05$. Hal ini berarti ada perbedaan antar masing-masing kedua model pembelajaran. Dengan melihat mean difference antar model pembelajaran didapat kesimpulan: 1) Pembelajaran dengan menggunakan TAI AfL lebih efektif daripada menggunakan pembelajaran TAI maupun langsung, 2) pembelajaran dengan menggunakan TAI lebih efektif daripada menggunakan pembelajaran model langsung. Saran peneliti bagi calon peneliti lainnya yaitu dengan penggunaan model pembelajaran yang kooperatif yang diintegrasikan dengan berbasis AfL terutama model pembelajaran TAI, hal ini terbukti memberikan pengaruh positif terhadap hasil belajar matematika. Selain itu, penelitian juga dapat dikembangkan untuk materi-materi yang lain dalam matematika.

\section{DAFTAR PUSTAKA}

Achdiyat, M., \& Andriyani, F. (2016). Hasil belajar matematika ditinjau dari model pembelajaran Teams Assisted Individualization (TAI). Formatif: Jurnal Ilmiah Pendidikan MIPA, 6(3). https://doi.org/10.30998/formatif.v6i3.996

Afifah, U. N., Suwandono, S., \& Oktaviani, D. N. (2018). Deskripsi Kemampuan Berpikir Kritis Peserta Didik dengan Model Pembelajaran Two Stay Two Stray. JIPMat, 3(2). https://doi.org/10.26877/jipmat.v3i2.2732

Agus Suprijono. (2011). Cooperative Learning Teori dan Aplikasi Paikem. Pustaka pelajar. Asriningsih, K., Renda, N, T., \& Wibawa, I, M, C. (2014). Pengaruh Model Pembelajaran Kooperatif Tipe Team Assisted Individualization (TAI) terhadap Hasil Belajar IPA 
Siswa Kelas Iv Sd Gugus V Kecamatan Banjar. Jurnal Mimbar PGSD Universitas Pendidikan Ganesha Jurusan PGSD, 2(1).

Attle, S., \& Baker, B. (2007). Cooperative learning in a competitive environment: Classroom applications. International Journal of Teaching \& Learning in Higher Education, 19(1).

Budiyono. (2011). Penilaian Hasil Belajar. Universitas Sebelas Maret.

Cahyani, E., Sarengat, S., \& Siswantoro, S. (2018). Pengaruh Pembelajaran Team Assisted Individualization terhadap Hasil Belajar Matematika Siswa Sekolah Dasar. Jurnal Pedagogi, 7(3).

Dewi, E. K., \& Yulia, P. (2018). Efektivitas Penerapan Model Pembelajaran TAI dan PBI terhadap Hasil Belajar Matematika Siswa Kelas VIII SMPN 50 Batam. PYTHAGORAS: Jurnal Program Studi Pendidikan Matematika, 7(2), 42-48. https://doi.org/10.33373/pythagoras.v7i2.1318

Fadila, A. (2016). Perbandinagn Hasil Belajar Matematika antara Penggunaan Media Berbasis Komputer dan Cetak. JURNAL E-DuMath, 2(1).

Goldman, J. D., \& Torrisi-Steele, G. (2002). Constructivist pedagogies of interactivity on a CD-Rom to enhance academic learning at a tertiary institution. International Journal of Educational Technology, 3(1), n1.

Gunawan, G. (2017). Pembelajaran berbasis TIK dengan Assessment for Learning (AfL) ditinjau dari kemampuan spasial siswa kelas VIII SMP negeri se-kota Banjarmasin. Math Didactic:Jurnal Pendidikan Matematika, 3(3), 199-209.

Halih, M. (2016). Pengaruh model pembelajaran TAI (team assisted individualization) terhadap hasil belajar siswa. Buana Matematika: Jurnal Ilmiah Matematika Dan Pendidikan Matematika, 6(2), 45-52. https://doi.org/10.36456/buanamatematika.v6i2:.368

Hariyati, E., Mardiyana, \& Usodo, B. (2013). Efektivitas Model Pembelajaran Kooperatif Tipe Team Assisted Individualization (TAI) dan Problem Based Learning (PBL) Pada Prestasi Belajar Matematika Ditinjau dari Multiple Intelligences Siswa Smp Kabupaten Lampung Timur Tahun Pelajaran 2012/2013. Jurnal Elektronik Pembelajaran Matematika, 1(7), 721-731.

Huda, M. (2014). Model-Model Pengajaran Dan Pembelajaran. Pustaka Belajar.

Irving, K. E. (2006). The Impact of Educational Technology on Student Achievement: Assessment. Science Educator, 15(1), 13-20.

Isabwe, G. M. N., Reichert, F., Carlsen, M., \& Lian, T. A. (2014). Using Assessment for Learning Mathematics with Mobile Tablet Based Solutions. IJET, 9(2). https://doi.org/10.3991/ijet.v9i2.3219

Jaya, P., Waridah, W., \& Ason, Y. (2016). Penerapan Model Pembelajaran Kooperatif Tipe Team Assisted Individualization (TAI) Berbasis Pendekatan Saintifik terhadap Hasil Belajar Matematika pada Siswa Sekolah Dasar. Jurnal Pendidikan Dasar, 4(1), 70-80. https://doi.org/10.46368/jpd.v4i1.102

Mawaddah, S., \& Maryanti, R. (2016). Kemampuan pemahaman konsep matematis siswa SMP dalam pembelajaran menggunakan model penemuan terbimbing (discovery learning). Edu-Mat: Jurnal Pendidikan Matematika, 4(1). https://doi.org/10.20527/edumat.v4i1.2292

Noor, N., \& Munandar, I. (2019). Pengaruh Model Pembelajaran Kooperatif (Tipe TAI dan TPS) dan Aktivitas Belajar terhadap Hasil Belajar Matematika. Jurnal Ilmu Pendidikan (JIP) STKIP Kusuma Negara, 11(1), 65-75.

Pajriana, I., \& Pujilestari, P. (2018). Pengaruh Metode Pembelajaran Team Assisted Individualization (TAI) terhadap Hasil belajar Matematika Siswa. Media Pendidikan Matematika, 4(2), 64-69. https://doi.org/10.33394/mpm.v4i2.372

Puspendik. (2017). Laporan Hasil Ujian Nasional : Daftar nilai wilayah dan satuan 
pendidikan. Kemdikbud.

Rakhmawati, R. (2015). Upaya meningkatkan aktivitas dan prestasi belajar matematika siswa kelas XI IPA 1 SMAN 1 Amuntai tahun pelajaran 2013/2014 melalui pembelajaran kooperatif tipe STAD. Math Didactic: Jurnal Pendidikan Matematika, 1(2), 116-123. https://doi.org/10.33654/math.v1i2.12

Slavin. (2010). Cooperative Leaarning Teori, Riset, dan Praktik. Nusa Media.

Sugiyono. (2011). Metode PenelitianKuantitatif, Kualitatif dan $R \& D$. Alfabeta.

Supriyanti, A. (2020). PREDIKSI JUMLAH CALON PESERTA DIDIK BARU MENGGUNAKAN METODE DOUBLE EXPONENTIAL SMOOTHING DARI BROWN ( Study Kasus : SD Islam Al-Musyarrofah Jakarta ). Jurnal Lebesgue : Jurnal Ilmiah Pendidikan Matematika, Matematika Dan Statistika, 1(1), 56-62. https://doi.org/10.46306/lb.v1i1

Sutriningsih, N. (2015). Model Pembelajaran Team Assisted Individualization Berbasis Assessment for Learning pada Persamaan Garis Lurus Ditinjau dari Karakteristik Cara Berpikir. JURNAL E-DuMath, 1(1). https://doi.org/10.26638/je.81.2064

Tarim, K., \& Akdeniz, F. (2008). The effects of cooperative learning on Turkish elementary students' mathematics achievement and attitude towards mathematics using TAI and STAD methods. Educ Stud Math, 67(1), 77-91. https://doi.org/10.1007/s10649-0079088-y

Tinungki, G., M. (2015). The Role of Cooperative Learning Type Team Assisted Individualization to Improve the Students' Mathematics Communication Ability in the Subject of Probability Theory. Journal of Education and Practice, 6(32), 27 - 31.

Tristanti, L. B. (2017). Pengaruh Model Pembelajaran Kooperatif Tipe TAI Dan Problem Based Learning (PBL) Terhadap Pemahaman Konsep Bangun Ruang Siswa. AKSIOMA: Jurnal Program Studi Pendidikan Matematika, 6(3), 338-349. https://doi.org/10.24127/ajpm.v6i3.1131 